\title{
Investment funding programs on dairy farms in Hajdú-Bihar County
}

\author{
Nándor Csatári - András Vántus \\ University of Debrecen Faculty of Agricultural and Food Sciences and Environmental Management, \\ Department of Agricultural Technology, Debrecen, Hungary \\ csatarin@agr.unideb.hu
}

\begin{abstract}
SUMMARY
The dairy farming sector needs constant modernization of its buildings, machines and technology in order to maintain its competitiveness and productivity. For the greater scale investments, these companies try to apply for state funds in addition to their own financial sources. Therefore, the investment support system plays a great role by improving the competitiveness and modernity of these farms. In the last 10 years, 7 funding programs were available for dairy farms. In this research, 25 dairy farms were interviewed in Hajdú-Bihar County. The examined farms cover more than 50\% of the milk production in Hajdú-Bihar County. The survey questions focused on the investment funding program use of farms between 2007 and 2017 and renewable energy investments including all programs. The results show how many tenders were submitted, how many were successfully evaluated and completed. All farms had at least two successfully evaluated projects. A correlation was found between completed projects by farm size and completed projects. The connection of the modernity index of dairy farms and the completed projects was also shown.
\end{abstract}

Keywords: dairy, investment, application, subsidy, renewable energy

\section{INTRODUCTION}

The dairy farming sector needs constant modernization of the buildings, machines and technology for the sake of its competitiveness and productivity. For the greater scale investments, these companies try to apply for state funds beside their own financial sources. Therefore, the investment support system plays a great role by improving the competitiveness and modernity of these farms. The funding project conditions are orienting those farms through evaluation systems to energy efficiency and renewable energy production.

The European Common Agricultural Policy (CAP) has two pillars. The $1^{\text {st }}$ pillar focuses on market instruments, income support, and it is funded by the European Agricultural Guarantee Fund (EAGF), while the $2^{\text {nd }}$ pillar focuses on rural development incentives (among the investment supports) and it is funded by the European Agricultural Fund for Rural Development (EAFRD; Hungarian abbreviation: EMVA) (EK 2006).

Based on the previous CAP budget period from 2007 to 2013, dairy farms have the opportunity to apply for 5 tender programs for investment support of Animal Farm Modernization Programs (Hungarian abbreviation: ÁTK I-ÁTK V). The different programs had slightly different conditions, but the main characteristics are the same. These supports were nonrefundable, and in order to win, a tender was needed to be submitted concerning which tender was evaluated according to the given scoring system. The grant was transferred after finishing an investment. After receiving the last sum of the financial support, the farm had to operate for at least five years in the same size (FVM 2007). Altogether 2300 tenders were successfully evaluated in the ÁTK programs; the average project support was 115.8 million HUF. In the end of 2013 year the distribution of paid support was the following: $38.2 \%$ was received by farm with maximum 50 hectares land size; $18.5 \%$ to farms with 50-500 hectares land, and $43.3 \%$ to farms above 500 hectare land, respectively (Bíró and Nemes 2014).

In the recent CAP budget 2 tenders were available for dairy farming sector; the programs were divided by animal sector, except the manure handling. The "VP Building manure containers" program had 5.57 billion HUF budget, only for small scale investment up to 50 million HUF each. The "VP Modernization of cattle farms" program had 19.86 billion HUF budget, for beef and dairy farms (NAK 2015). The application period was closed in both programs because the submitted tenders covered the budget. The decision of the won tenders was published in December 2016 in "VP Building manure containers" program and November 2017 in "VP Modernization of cattle farms". It is not expected to open another investment support program tenders in the 2014-2020 CAP budget, however the amount of income support given to the dairy sector will remain constant by 2020 .

The CAP budget after 2020 is under negotiation, but it is expected that the amount of the support both in income supports and in investment supports will significantly decrease, the latter may cease and only interest support will remain instead. That's why it is essential for the dairy farms to improve their competitiveness and perform their modernization by 2020 .

\section{MATERIALS AND METHODS}

During this survey, 25 dairy farms examined in Hajdú-Bihar County, the questioning happened on March and April 2017. Hajdú-Bihar County has the most dairy cow and milk production in Hungary (KSH 2017), Furthermore the average milk yield per cow (H-B County: 24 liter/day - Hungary 23.5 liter/day) and the average dairy farm size (H-B County: 396 cows - Hungary 396 cows) are closely similar to the national average (ÁT Kft. 2016a). Therefore, the 
conclusions made in this county have a relevance to the Hungarian dairy farming sector.

The representativeness of the survey was examined with the help of the available statistic sources (National Statistic Office - KSH; Association of Hungarian Holstein-Friesian Cattle Breeders - HfTE and Livestock Performance Testing Ltd. - ÁT Kft.).
The share of examined farms is indicated in Table 1. The share of the examined farms is calculated between 41 to 67 percent according to the different aspects. The number of dairy cows in the examined farms has a share of 7.17 percent among the Hungarian total performance tested dairy cows.

Share of examined farms compare to Hajdú-Bihar County by different aspects

\begin{tabular}{|c|c|c|c|c|}
\hline Aspect & Data source & H-B County & $\begin{array}{c}\text { Examined } \\
\text { farms }\end{array}$ & $\begin{array}{c}\text { Share } \\
(\%)\end{array}$ \\
\hline Number of dairy cows in 2016 & $\mathrm{KSH}$ and own data collection & 31750 & 13142 & 41 \\
\hline Annual milk production 2016 (thousand liter) & KSH and own data collection & 203053 & 117991 & 58 \\
\hline Number of performance tested dairy farms, average 2016 & ÁT Kft., KSH and own data collection & 52 & 25 & 48 \\
\hline Number of performance tested dairy cows in 2016 & ÁT Kft., KSH and own data collection & 20656 & 13142 & 64 \\
\hline $\begin{array}{l}\text { Estimated annual milk production in } 2016 \\
\text { (number of lactations x lact. average) (tons) }\end{array}$ & HfTE & 179864 & 120504 & 67 \\
\hline
\end{tabular}

Source: own editing on the basis of KSH (2017), HfTE (2017), ÁT Kft. (2016a-1) and own data

The size distribution of dairy farms is shown in Table 2. It highlights that in all size categories the representativeness is above $50 \%$, except the farm size category between 51 and 200. The accurate farm list data was provided by HfTE (2017).

Table 2

Distribution of dairy farms by size, according year 2016

\begin{tabular}{lccc}
\hline $\begin{array}{c}\text { Size category } \\
\text { (number of standard } \\
\text { lactations) }\end{array}$ & $\begin{array}{c}\text { All dairy in } \\
\text { Hajdú-Bihar } \\
\text { County } \\
\text { (pcs) }\end{array}$ & $\begin{array}{c}\text { Examined } \\
\text { farms } \\
\text { (pcs) }\end{array}$ & $\begin{array}{c}\text { Share } \\
(\%)\end{array}$ \\
\hline Above 1 000 & 3 & 2 & 67 \\
701 to 1 000 & 4 & 2 & 50 \\
501 to 700 & 9 & 6 & 67 \\
301 to 500 & 8 & 5 & 63 \\
201 to 300 & 5 & 4 & 80 \\
51 to 200 & 13 & 6 & 46 \\
\hline Altogether & 42 & 25 & 60 \\
Under 50 & 8 & - & - \\
\hline
\end{tabular}

Source: own editing on the basis of KSH (2017) and HfTE (2017)

The 25 farms were separated to 3 clusters according to the cow number. The Cluster 1 contained farms with cow below 400 (11 farms), Cluster 2 contained farms between 401 and 600 ( 7 farms), and Cluster 3 contained farms above 601 cows ( 7 farms). In this article the names of the farms are not indicated, they are only referred with a number (Farm1, F2, F3 etc.), but the numbers are used in descending order by cow number in farms.

The survey questions covered the general farm data, (cow number, number of employees), the technical characteristics (barn technology, milking technology, etc.), and the activity in investment funding programs in the recent 2014-2020 and the previous 2007-2013 CAP budget period. Altogether 7 funding programs were available for dairy farm to give a financial support for the technical modernization in the given period, 5 in the previous, and 2 in the recent CAP budget.

\section{RESULTS AND DISCUSSION}

The practice of project proposals and funding has been analysed through the number of submitted, won and implemented projects on farm level. However, the projects in these farms have different size in term of sum, and the relative size to the farm's turnover, but these economic aspects were not examined. Nevertheless, a tendering opportunity for a farm was available rarely (only few time in a decade), therefore each farm tried to maximize its project size within their financial possibilities and the funding program constraints. The most severe limiting factor was the finance, and several farms had to cancel the won projects because of their difficulties to gather the financial sources (e.g. F04, F15, F18).

The number of submitted, won and implemented projects of each dairy farm in the last 10 years is shown in Figure 1. Each dairy farm (except F25) has submitted and won at least 2 projects and implemented at least 1 during the examined period. The two biggest farms were completed the most (4) tenders (F01, F02), 7 farms completed 3 tenders, 10 farms completed 2 tenders and 5 farms completed only one tender. In Cluster 1 (smaller farms) the average completed tendering program was 1.55 , in Cluster 2 was 2.57, in Cluster 3 the average completed project count was 2.71 and the mean was 2.16 . 
Figure 1: Number of funding projects in examined dairy farms between 2007 and 2017

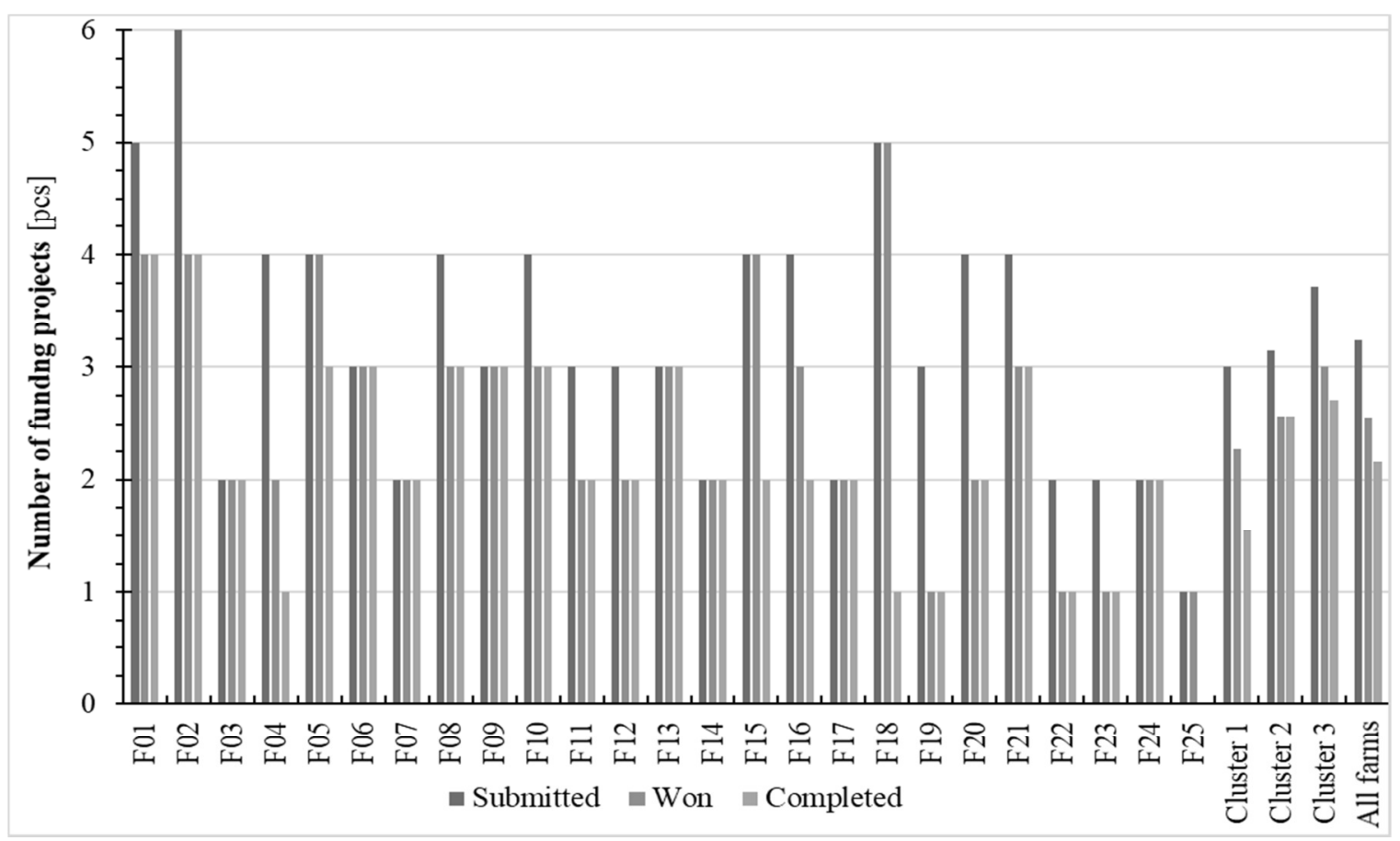

Source: own editing

Distribution of project proposals by program and cluster is shown in Table 3. In the case of the last funding program: VP Modernization of dairy farms grey lines indicate that the given activity has not finished yet, therefore it was not available at the time of data collection. The number of won projects is not complete, however 8 projects were rejected, 3 farms have no data available or funding decision from that project is in progress. The completed line is empty, because the completion period ends at November 2019.

Distribution of tendering programs by cluster

\begin{tabular}{|c|c|c|c|c|c|}
\hline $\begin{array}{l}\text { Tendering } \\
\text { program }\end{array}$ & Result & Cluster 1 & Cluster 2 & Cluster 3 & All clusters \\
\hline \multirow{3}{*}{ EMVA ÁTK I. } & Submitted & 6 & 3 & 6 & 15 \\
\hline & Won & 6 & 3 & 6 & 15 \\
\hline & Completed & 5 & 3 & 5 & 13 \\
\hline \multirow{3}{*}{$\begin{array}{c}\text { EMVA ÁTK } \\
\text { II. }\end{array}$} & Submitted & 3 & 3 & 3 & 9 \\
\hline & Won & 3 & 3 & 3 & 9 \\
\hline & Completed & 1 & 3 & 3 & 7 \\
\hline \multirow{3}{*}{$\begin{array}{l}\text { EMVA ÁTK } \\
\text { III. }\end{array}$} & Submitted & 2 & 3 & 1 & 6 \\
\hline & Won & 2 & 3 & 1 & 6 \\
\hline & Completed & 1 & 3 & 1 & 5 \\
\hline \multirow{3}{*}{$\begin{array}{l}\text { EMVA ÁTK } \\
\text { IV. }\end{array}$} & Submitted & 3 & 4 & 6 & 13 \\
\hline & Won & 3 & 3 & 6 & 12 \\
\hline & Completed & 1 & 3 & 6 & 10 \\
\hline \multirow{3}{*}{$\begin{array}{c}\text { EMVA ÁTK } \\
\text { V. }\end{array}$} & Submitted & 8 & 6 & 3 & 17 \\
\hline & Won & 8 & 6 & 3 & 17 \\
\hline & Completed & 8 & 6 & 3 & 17 \\
\hline \multirow{3}{*}{$\begin{array}{c}\text { VP Building } \\
\text { manure } \\
\text { containers }\end{array}$} & Submitted & 4 & 0 & 3 & 7 \\
\hline & Won & 1 & 0 & 1 & 2 \\
\hline & Completed & 1 & 0 & 1 & 2 \\
\hline \multirow{3}{*}{$\begin{array}{c}\text { VP } \\
\text { Modernisation } \\
\text { of dairy farms }\end{array}$} & Submitted & 7 & 3 & 4 & 14 \\
\hline & Won & 2 & 0 & 1 & 3 \\
\hline & Completed & 0 & 0 & 0 & 0 \\
\hline \multirow{3}{*}{ All } & Submitted & 33 & 22 & 26 & 81 \\
\hline & Won & 25 & 18 & 21 & $\overline{64}$ \\
\hline & Completed & 17 & 18 & 19 & 54 \\
\hline
\end{tabular}

Source: own editing 
ÁTK I and ÁTK II programs have been very popular, 15 and 9 projects have been implemented by the dairy farms respectively. In the case of ÁTK III, low submission activity might be caused by the call conditions (previous projects had to be closed) and by financial issues (implementation and payment of loan instalments is a huge burden for the dairy farms). Popularity of the ÁTK V program has been confirmed by the data of the examined farms, since $68 \%$ of the farms have implemented machinery and equipment development with the help of project funding. Project proposals for the call "VP Construction of manure storage buildings" have been submitted by 5 farms, 2 of them has won, those were implemented in 2017. The "VP Modernization of cattle farms" was also popular, by 14 submitted projects among the examined farms.

In this research there were connection between renewable energy investments and the funding system:

- Two biogas plants have operated in relation with the examined dairy farms; both of them have been constructed in the scope of the ÁTK 1 manure management program at a funding rate of $75 \%$. A third farm also won in ATK I. tender, but they cancelled the project.

- No photovoltaic solar cells were observed in the farms although it was an eligible expenditure in funding programs.

- Solar thermal collectors have been operated at 5 dairy farms; all of them have been based on project funding. Four of them were completed in the scope of the ATK 4 tendering program, and the additional 10 points in project evaluation due to renewable energy was a strong incentive for these solar collectors

- Biomass boilers are used at 5 farms and although it was an eligible expenditure in funding programs, all of them are based on own resources.

Project activity of the examined dairy farms has been compared through two factors. First, the correlation between farm size (cow number) and the number of implemented projects has been analyzed; this is shown in Figure 2. Results of correlation and regression calculation have been the following: Value of the Pearson correlation between the two series of data is 0.682, which indicates a close, positive correlation. The value ' $m r$ ' is 0.107 , its treble, 0.321 is lower than the absolute value of the correlation coefficient, therefore correlation is confirmed. The critical ' $\mathrm{t}$ ' is 3.767 at $(\mathrm{P}<0.001 \%)$ level of significance, the calculated ' $t$ ' value is 4.47 , which is higher than the critical ' $t$ ' values, therefore the deviation from 0 of the correlation coefficient is not by accident with $99.9 \%$ probability. The resulted linear regression function is the following: $1.38+0.0015 \mathrm{x}$, the function fits medium. Thus, farms with a higher number of cows implemented more projects.

\section{Figure 2: Correlation of farm size and implemented projects}

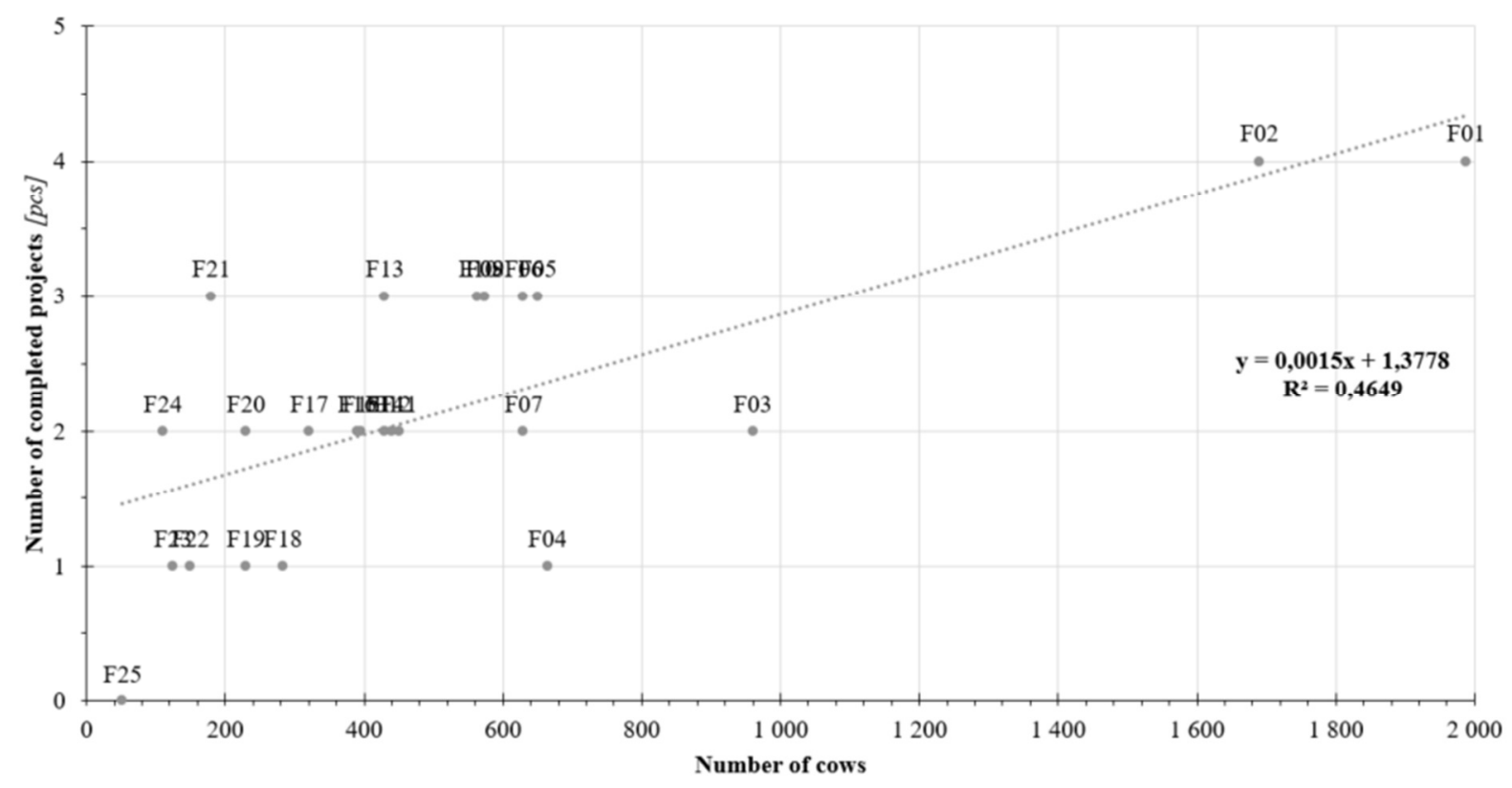

The next graph shows the correlation between the completed tendering programs and the modernity index of the examined farms. The modernity index was calculated from the main technical of the farms summarizing the effect of 31 technical characteristic characteristics (milking, feeding, barn technology etc.) to the milk yield, labour productivity and energy efficiency. The correlation is shown in Figure 3. 
Figure 3: Completed tendering programs and the modernity index

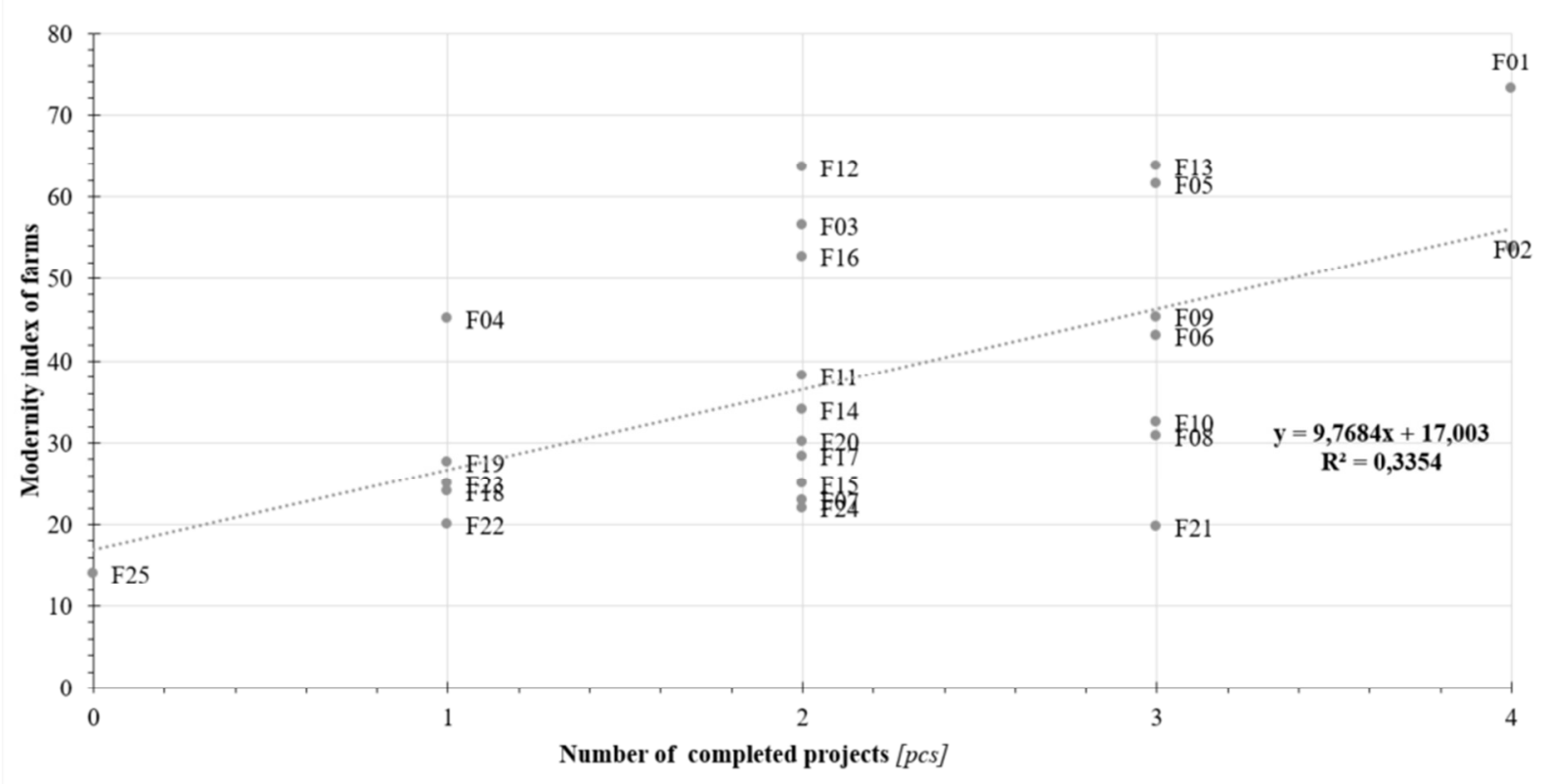

Results of correlation and regression calculation have been the following: Value of the Pearson correlation between the two series of data is 0.579 , which indicates a close, positive correlation. The value ' $m r$ ' is 0.133 , its treble, 0.399 is higher than the absolute value of the correlation coefficient, therefore correlation is confirmed. The critical ' $t$ ' is 2.807 at $(\mathrm{P}<0.01 \%)$ level of significance, the calculated ' $\mathrm{t}$ ' value is 3.41 , which is higher than the critical ' $\mathrm{t}$ ' values, therefore the deviation from 0 of the correlation coefficient is not by accident with $99 \%$ probability.

The resulted linear regression function is the following: $17+9,77 x$, the function fits medium. Thus, farms with more implemented projects tend to have higher modernity index score.

\section{CONCLUSION}

Summarizing the findings of this paper, the examined dairy farms try to utilize investment support sources for their investments. The examined 20 dairy farms submitted 81, won 64 and completed 51 tendering projects. The most popular tenders were ÁTKI and ÁTK V. The bigger dairy farms were able to participate and realize more projects than the smaller farms. These tenders gave incentives for renewable energy application because all completed biogas and solar thermal collectors were part of a tendering project. After 2020 the future accessibility of these investment support fund is a question, therefore dairy farms have to perform their modernization before that date.

\section{REFERENCES}

Állattenyésztési Teljesítményvizsgáló Kft. (2016a) Partnertájékoztató Hírlevél. 2016. XIV. évf. 12. szám.

Állattenyésztési Teljesítményvizsgáló Kft. Partnertájékoztató Hírlevél. 2016. XIV. évf. 1. szám.

Állattenyésztési Teljesítményvizsgáló Kft. Partnertájékoztató Hírlevél. 2016. XIV. évf. 2. szám.

Állattenyésztési Teljesítményvizsgáló Kft. Partnertájékoztató Hírlevél. 2016. XIV. évf. 3. szám.

Állattenyésztési Teljesítményvizsgáló Kft. Partnertájékoztató Hírlevél. 2016. XIV. évf. 4. szám.

Állattenyésztési Teljesítményvizsgáló Kft. Partnertájékoztató Hírlevél. 2016. XIV. évf. 5. szám.

Állattenyésztési Teljesítményvizsgáló Kft. Partnertájékoztató Hírlevél. 2016. XIV. évf. 6. szám.

Állattenyésztési Teljesítményvizsgáló Kft.

Partnertájékoztató Hírlevél. 2016. XIV. évf. 7. szám.
$(2016 b)$

(2016c):

(2016d):

(2016e):

(2016f):

(2016g):

(2016h):
Állattenyésztési Teljesítményvizsgáló Kft. Partnertájékoztató Hírlevél. 2016. XIV. évf. 8. szám.

Állattenyésztési Teljesítményvizsgáló Kft. Partnertájékoztató Hírlevél. 2016. XIV. évf. 9. szám.

Állattenyésztési Teljesítményvizsgáló Kft. Partnertájékoztató Hírlevél. 2016. XIV. évf. 10. szám.

Állattenyésztési Teljesítményvizsgáló Kft. (20161): Partnertájékoztató Hírlevél. 2016. XIV. évf. 11. szám.

Bíró Sz.-Nemes G. (2014): Vidékfejlesztési támogatások, lehívások, eredmények. Gazdálkodás. 58. 3: 247-262.

EK (2006): Az EU vidékfejlesztési politikája 2007 és 2013 között. Európai Közösség Bizottsága.

FVM (2007): 23/2007. (IV.17.) FVM rendelet az Európai Mezőgazdasági Vidékfejlesztési Alap társfinanszírozásában megvalósuló támogatások igénybevételének általános szabályairól, a jogszabály módosításokkal egységes hatályos szövege. http://njt.hu/cgi_bin/njt_doc.cgi?docid=109479. 333276, downloaded 20th Nov. 2017 
HfTE (2017): Tenyészetek, telepek megyei rangsora a holstein-fríz egyedek standard laktációs tejtermelése alapján 2016. 01. 012016. 12. 31. http://www.holstein.hu/teb/orsz/megyei_50_ 2017.pdf, downloaded 20th Nov. 2017
KSH (2017): Szarvasmarha-állomány, december 1. (2000-2016) STADAT tábla 6.4.1.19. http://www.ksh.hu/docs/hun/ xstadat/xstadat_eves/i_oma004.html, downloaded 20th Nov. 2017

NAK (2015): Nemzeti Agrárgazdasági Kamara, Vidékfejlesztési Program Kézikönyv. 92. 